\title{
DWA SYSTEMY DOBRA? - FENOMEN SPRAWNOŚCI
}

\section{1. „Naturalność" dobra?}

„Systemów" dobra jest tyle, ile systemów, w których ta wartość funkcjonuje. Inaczej wygląda dobro $w$ sporcie, inaczej w przedsiębiorstwie, inaczej w moralności, a jeszcze inaczej w religii. Jak można zestawiać ze sobą tak różne systemy?

Zapożyczam, na potrzeby refleksji o dobru, systemowe ujęcie życia społecznego od Niklasa Luhmanna, autora nie tylko Systemów społecznych, w której to rozprawie wykłada on teorię systemowego ujęcia kultury, ale także książki o systemie religijnym pod tytułem Funkcja religii.

W ujęciu Luhmanna, nowoczesne społeczeństwo składa się z funkcjonalnych podsystemów, które posiadają znaczną autonomię (swoboda produkcji informacji o systemie) i ograniczoną zdolność komunikacji między sobą. Komunikacja ma przede wszystkim miejsce wewnątrz systemów, a nie pomiędzy nimi. Systemy, mimo że się nie komunikują, to wzajemnie się wchłaniają ${ }^{1}$. Na przykład moda wchłania dziś sztukę, a obyczajowość wchłania moralność. Dopiero na własnym polu (systemu) odbywa się dyskusja o wartościach i normach (rzekomo uniwersalnych).

Przez „system” rozumie Luhmann procesualny i dynamiczny efekt wytwarzania różnic. $W$ ten sposób system się rozrasta, odróżniając się od innych systemów. Takie ujęcie zastępuje klasyczne, strukturalistyczne, dosyć stabilne ujęcie systemu jako po prostu różnicy między całością i częścią.

${ }^{1}$ N. Luhmann, Systemy społeczne. Zarys ogólnej teorii, tłum. M. Kaczmarczyk, Kraków 2007. 
W konsekwencji, relacja systemowa to relacja między systemem a wszystkim, co nim nie jest. System nie tyle więc istnieje w jakimś otoczeniu lub poza nim, co jest od niego odróżnialny.

Na początku mamy więc nie tożsamość, a różnicę. Tylko dzięki temu przypadek może mieć wartość informacyjną i może służyć do budowania porządku. Wszak informacja nie jest niczym innym, jak zdarzeniem, które skutkuje powiązaniem różnic "a difference that makes a difference" 2 .

Systemy (funkcjonujące w obrębie nad-systemu społecznego) są odrębne i bronią swojej odrębności, programując w zawrotnym tempie swoje zasady.

Dziś kategoria dobra zawiera się $w$ różnych systemach, ale najlepiej funkcjonuje wciąż $\mathrm{w}$ systemie moralnym, religijnym i w systemie ekonomiczno-politycznym jako wartość wymienna (o towarach też mówi się „dobra"). Przy czym w systemie moralnym, obyczajowym i religijnym dobro wydaje się kategorią "naturalną", odniesieniem idealnym, wartością niewymienialną na inne.

Normy życia społecznego mają postać nakazów, dyrektyw, związanych z realizacją wartości. Na przykład przykazanie „Nie zabijaj” dotyczy wartości życia. Dopiero wartości ujęte w normy można uzasadniać, propagować, zwalczać, konfliktować ze sobą. Najbardziej znany przykład wartości to starożytna triada Dobra, Prawdy i Piękna. Określenie hierarchii wartości to przypisanie wartościom stopnia ważności. Najczęściej konflikty i kryzysy związane z realizacją wartości lub dążeniem do nich ujawniają osobistą hierarchię wartości. Sytuacje, w których człowiek dokonuje wyboru między wartościami, rewiduje swoją hierarchię wartości, nazywane są dylematami etycznymi, bo wymagają często poświęcenia jakiejś wartości na rzecz innej.

Gdy ustanowimy - tak jak opisał to Roland Barthes - silnie, a zarazem subtelnie zorganizowane systemy semiologiczne, przemieniające rzeczy w znaki, czyli gdy jakąś dziedzinę życia zinstytucjonalizujemy, użytkownicy systemu podejmą natychmiast niestrudzoną działalność, aby ukryć, zamaskować ich systemową naturę. To znaczy będą traktowali instytucjonalną (systemową) organizację jako formalność niemającą wpływu na ich decyzje $\mathrm{w}$ danej dziedzinie. Jest to typowy proces mitologiczny ${ }^{3}$.

Barthes podaje trzy główne cechy systemu (semantycznie doskonałego, takiego jak np. moda): zamkniętość, pustość i zwrotność ${ }^{4}$. Uzupełnia też Jakobsonowski mechanizm języka, oparty na synchronicznej osi metafory

\footnotetext{
2 Ibidem, s. 76.

${ }^{3}$ Zob. R. Barthes, Mitologie, tłum. A. Dziadek, Warszawa 2000.

${ }^{4}$ R. Barthes, System mody, tłum. Maciej Falski, Kraków 2005, s. 285.
} 
i diachronicznej osi metonimii, osią parataksy. Czyli obok zagęszczenia i przesunięcia znaczenia, mamy trzeci jego wymiar - zestaw, stanowiący o zwrotności systemu. Im bardziej nieokreślony jest system, z im większą ilością zjawisk pozwala się zestawiać, tym lepiej działa. Parataksa wzmacnia metonimię (jako strategię przesunięć) i ostatecznie rozluźnia metaforę (jako jednolity obraz całości).

Barthes buduje projekt semiologii jako przebudowy lingwistyki ${ }^{5}$. Ma ona za zadanie badać, "w jaki sposób społeczeństwo produkuje stereotypy, to jest nadwyżki sensu", i konsumuje je jako „sensy naturalne" 6 . W ten sposób obala mit czystej kreatywności - myślimy bowiem znakami, a nie ideami. Znaki to idee zapożyczone $\mathrm{w}$ reprezentacjach, przedstawieniach. Mamy w systemach etycznych, normatywnych, założenie o „naturalności” dobra (pewną czystą ideę dobra najwyższego) i często sprzeczną z nim systemową dyskursywną logikę normatywną, która uzależnia konkretnie osiągane dobro od danej relacji tworzącej sytuację komunikacyjną między użytkownikami języka, reprezentującymi często sprzeczne interesy i sprzeczne wizje dobra.

\section{Tragiczność wyboru dobra}

Powszechna potrzeba sprawiedliwości społecznej zdominowana jest logiką procesu, twierdzi Adolphe Gésche, czyli tłumaczenia ludziom obiektywności moralnych kategorii - dobra i zła - i ich wymienności na czyny, towary, inne wartości7.

W podobnym duchu logikę procesu opisze Jean-François Lyotard poprzez kategorię „poróżnienia”. Francuskie pojęcie le différend („zatarg”) zostaje przetłumaczone przez Bogdana Banasiaka jako "poróżnienie”, żeby podkreślić niemożność ustalenia wspólnego idiomu komunikacyjnego odrębnych dyskursów.

Zatargu nie da się rozstrzygnąć, ponieważ nie ma reguł, według których można by adekwatnie osądzać sprzeczne stanowiska. Uregulowanie zatargu, zdaniem Lyotarda, może dokonać się tylko w specyficznym dyskursie (idiomie) jednej ze stron, ale druga strona jest wówczas pokrzywdzona. Krzywda z kolei też pozostaje niewyrażalna w idiomie, w którym zatarg

${ }^{5}$ R. Barthes, Wykład, tłum. T. Komendant (fragmenty wykładu inauguracyjnego w Collège de France z 7 stycznia 1977 r.), ,"Teksty” 1979, nr 5, s. 21.

6 Ibidem, s. 22

7 A. Gesché, Zło, tłum. A. Kuryś, Poznań 2009. 
został rozstrzygnięty. Prawdziwą krzywdą jest bowiem nie móc o niej opowiedzieć 8 .

Czynienie sprawiedliwości polega na znalezieniu idiomu, w którym może być wyrażona krzywda jednej ze stron. Zadaniem filozofii, według Lyotarda, jest poszukiwanie takich idiomów, czyli języka opartego o wspólne reguły i wartości. Dla zatargu idiom jest tylko potencjalnością, bo konkretna próba ustanowienia jakiegoś konsensusu między stronami sporu zawsze wyrządza krzywdę jednej $\mathrm{z}$ nich. W każdej mowie bowiem następuje co najwyżej zamiana zatargu w spór, który pozornie można rozwiązać - ma miejsce maskowanie istnienia zatargu9.

Mityczny przykład zatargu znajdujemy w literaturze w postaci Antygony. Antygona Sofoklesa nazywana jest tragedią władzy. Jest to ciąg dalszy rodzinnej tragedii Edypa, niejako konsekwencja wywyższenia systemu pokrewieństwa nad wszelkimi innymi systemami władzy. Antygona to tragiczne zwycięstwo polityki nad systemem pokrewieństwa. Główna bohaterka musi wybierać pomiędzy prawem boskim (pochowaniem brata zgodnie z zasadami religijnymi) i prawem ludzkim (postępowanie zgodnie z prawem ustanowionym przez Kreona). Z kolei Kreon albo będzie postępował zgodnie z wydanym rozkazem (kto pochowa zdrajcę, zginie), albo zostanie mu postawiony zarzut, że nagina prawo do własnych potrzeb (Antygona jest jego krewną).

W koncepcji Lyotarda każda próba kontaktu z inną narracją kończy się walką, czyli próbą przekonania partnera do własnych zasad. Pojedyncze narracje nie mogą być poddawane ocenie, bo nie mamy na poziomie pojedynczych narracji żadnych kryteriów tej oceny. Nawet prawo państwowe staje się kolejną "małą narracją”, którą można akceptować bądź nie. Koncepcję Lyotarda trudno obronić przed zarzutem samozwrotności.

Dla Jacques'a Rancière'a, podobnie ujmującego dylemat polityczności, wspólnota oparta na solidarności (wszyscy jesteśmy „my”) wymaga wspólnej metafory, jak również przyjęcia tego, że jest to metafora, nie pojęcie ${ }^{10}$.

Skrajna sytuacja nieporozumienia wynika, według Rancière'a, z tego, że któraś ze stron konfliktu nie widzi wspólnego obiektu, ponieważ go nie oznacza, nie posiada nawet znaków, chociażby dźwiękowych, na jego oznaczenie. Dodatkowo, sama aporia polityki jest utrzymanym obiektem filozoficznym. Jest ona wypróbowaniem następującej hipotezy: tak zwanej filozofii politycznej mogą być poddane wszystkie działania i myśli, w których

8 J.-F. Lyotard, Poróżnienie, tłum. B. Banasiak, Kraków 2010, s. 9-10.

${ }^{9}$ Zob. ibidem.

10 Zob. J. Rancière, Le Mésentente. Politique et philosophie, Galilée, Paris 1995, s. 84-91. 
filozofia próbuje pozbyć się polityki, znieść skandal myśli. Ów skandal ma swoje źródło w zabiciu Sokratesa, mordzie fundującym Platońską politeię. Politeia to wspólnota forsująca swoje wewnętrzne principia na wszystkie manifestacje życia, skąd wypływa Platońskie rozróżnienie na idealną republikę i zepsutą demokrację $e^{11}$.

Zdaniem Rancière'a, są tylko dwie kategorie ludzi - ci, którzy mają głos, i ci, którzy go nie mają. Polityka istnieje dzięki temu podziałowi. Platon, jego zdaniem, źle rozłożył akcenty: polityką mieli się zająć filozofowie, którzy należeli do sfery etyki (poznali głównie idee, czyli rzeczy same w sobie). Każda wiedza jest zawsze podzielna na części (partie), dlatego cała polityka składa się z części (partii). U Platona obserwujemy rozdzielność fenomenu fonicznego od logicznego - ci, którzy mówią, siedzą w jaskini, ci, którzy znają idee, wydostali się na zewnątrz i nie potrzebują mówićn ${ }^{12}$. Nie ma między nimi komunikacji.

U Lyotarda i Rancière'a mamy więc opisany rozdźwięk w obrębie samej etyki polegający na tym, że nie obejmuje ona całej normatywności (na przykład normatywności prawnej), bo dobro jest najbardziej mglistą z wartości i umyka ujęciu dyskursywnemu, podczas gdy ujęciu takiemu nie umyka ani wartość prawdy, ani piękna.

\section{Dwie najpopularniejsze różnice w ujęciach dobra}

W filozofii wciąż walczą ze sobą dwa ujęcia dobra - jedno wywodzi się od Platona, drugie od Arystotelesa. Jedno przedstawia dobro jako „idealny”, ostateczny punkt odniesienia, drugie raczej stawia na jego „procesualny", a nawet "sprawnościowy" charakter.

U Platona mamy ideę dobra nadrzędną nad wszystkimi pozostałymi ideami („Na szczycie świata idei świeci idea dobra”), u Arystotelesa mamy praktyczną postawę pozwalającą realizować dobro (postawa człowieka "słusznie dumnego" w Etyce nikomachejskiej). Kontynuacją linii Platońskiej jest Kantowski imperatyw praktycznego rozumu: „Postępuj tylko wedle takiej maksymy, co do której mógłbyś jednocześnie chcieć, aby stała się ona prawem powszechnym". Linię Arystotelejską na gruncie chrześcijaństwa kontynuuje św. Tomasz Akwinanta. Wprawdzie cnotą łączącą wszystkie inne jest $\mathrm{u}$ niego posłuszeństwo (stanowiące podstawę dla wyrzeczenia,

11 Zob. ibidem, s. 95-103.

12 Zob. ibidem, s. 44-49. 
czyli czystości i ubóstwa), to jednak „łaska buduje na naturze”, więc natury nie należy negować, lecz mądrze ograniczyć. Przy czym cel tego ograniczenia realizuje się w imperatywie niemalże ujętym po Kantowsku, "gdyż wola miłowania Boga jest więcej ochocza, im bardziej to, co czynimy albo znosimy dla Niego, sprzeciwia się naszej woli"13.

Platon, chcąc zachować ideę dobra jako najwyższą, przeniósł systemowość procesu wdrażania w tę ideę na edukację (Państwo). W Państwie można szukać powiązania dwóch tradycji w rozumieniu dobra: jako ulokowanej w najwyższej Idei (lub Bogu) i „sprawnościowej”, związanej z kształtowaniem określonej postawy. Platońska i Kantowska koncepcja dobra realizuje się poprzez założenie o „równości” członków wspólnoty (równy podział nie tylko dóbr, ale też wrażliwości $\left.{ }^{14}\right)$. Przy abstrakcyjnym rozumieniu równości pojawia się specyficzna separacja mocy (dobra) od dominacji (władzy). Stąd biorą się dwa ujęcia wolności (jako pochodnej dobra) - opartej na dostępie do "mocy" (hierarchia wyznawców) i wolności wszechobecnej (demokratyczna wolność równych), dominującej w społeczeństwie nowożytnym, ale biernej - nihilistycznej15. Fryderyk Nietzsche krytykuje Platońskie założenie o idealności „dobra”, bo ustanawia ono tak zwaną moralność panów i niewolników. Odmienność podejścia Nietzschego do wartości, możliwość "przewartościowania wszystkich wartości”, pozwala mimo wszystko ustawić jego myśl w tradycji Arystotelesa, ze względu na założenie o „sprawności”, czyli możliwości ćwiczenia się we właściwych (dobrych) działaniach. Sprawność, jako cel wyróżniający zwłaszcza człowieka współczesnego, podkreśla Peter Sloterdijk, spadkobierca Nietzschego. Pozostałość po działaniu "filozoficznego młota” Nietzschego to "neoascetyczne wskazówki trenerskie" w każdej dziedzinie naszego życia: "Jak zawsze przy lekturze Zaratustry nie wolno i tutaj dać się zwieść ewangelicznym tonom. W rzeczy samej nie mamy tu do czynienia $\mathrm{z}$ instrukcjami neoreligijnymi, ale raczej z neoascetycznymi wskazówkami trenerskimi" 16 .

"Sprawność, jako fenomen opisany przez Nietzschego, pozostaje odniesiona do wartości dobra, ale traci swój teleologiczny charakter, nie mówiąc już o charakterze eschatologicznym, staje się dobrem samym w sobie - hexis i habitus zostają na siebie nałożone.

${ }^{13}$ Św. Tomasz z Akwinu, O doskonałości życia duchowego, [w:] idem, Dzieła Wybrane, tłum. J. Salij OP, Poznań 1984, s. 233.

${ }^{14}$ T. May, The Political Thought of Jacques Rancière. Creating Equality, Edinburgh 2008, s. 114.

${ }^{15}$ Ibidem, s. 126.

${ }^{16}$ P. Sloterdijk, Musisz życie swe odmienić. O antropotechnice, tłum. J. Janiszewski, Warszawa 2014, s. 155. 
Pierre Bourdieu, eksponując pojęcie habitusu, traktuje je jako coś w rodzaju „ekonomii miejsca własnego"17 - stwierdzi Michel de Certeau. Dokonana przez de Certeau krytyka teorii habitusu Bourdieu zasadza się na stwierdzeniu, że występuje $\mathrm{w}$ tej myśli za dużo określonego miejsca jako miejsca, które wchłania wszystko wokół ${ }^{18}$. Bourdieu uzyskuje to miejsce (w którym rodzi się habitus), nakładając system kultury na system edukacji. Zewnętrzny habitus wcielony zostaje w hexis - trwałą dyspozycję, jak u Platona.

Hexis i habitus jako wyjaśnienia tego absorbującego stanu rzeczy, że ludzie, o ile działają moralnie i estetycznie, określeni są już od zawsze przez posiadające bycie-posiadanym, naznaczające bycie-naznaczonym, dysponujące bycie-dysponowanym, działające bycie-poddanym-działaniu - stanowią o wiele więcej niż tylko pojęcia pomocnicze krytycznej socjologii ${ }^{19}$.

Pytanie pojawiające się na linii refleksji Arystotelejskiej, którą można pociągnąć aż do Nietzschego, jest pytaniem o możliwość indywidualnego „wcielenia” dobra. U Platona i Kanta jest ono wcielone jako idea, obywatele mają więc taką samą wrażliwość na dobro, jest ono niezależne od ich indywidualnej wrażliwości, jest ponadjednsotkowe. U Arystotelesa natomiast jest wyborem.

\section{Pytanie o tak zwane dobro wieczne, czyli dobro wiecznie utrwalone}

W teologii pojawia się przede wszystkim ujęcie dobra jako wyboru, i to wyboru uczynionego ze względu na Kogoś, nie ze względu na samo dobro. Św. Katarzyna ze Sieny w swojej mistycznej wizji na temat Bożej Opatrzności zwraca uwagę, że ludzie działający bez łaski Bożej, cokolwiek dobrego by nie czynili, nie osiągną dobra wiecznego ${ }^{20}$, ponieważ nie robią tego ze względu na Boga. I chociaż nie powinni zaprzestawać dobrych czynów (bo każdy dobry czyn otrzymuje nagrodę, a grzech karę), dobro spełniane poza łaską nie zasługuje na życie wieczne; wyczerpuje się jakby samo w sobie.

${ }_{17}$ M. de Certeau, Heterologies, Discourse on the Other, transl. B. Massumi, London - Minneapolis 2000 , s. 56 .

18 Ibidem, s. $56-57$.

${ }^{19}$ P. Sloterdijk, op. cit., s. 256.

${ }^{20}$ Św. Katarzyna ze Sieny, Dialog o Bożej Opatrzności, czyli Księga Boskiej Nauki, tłum. L. Staff, Poznań 2001, s. 209. 
Boska dobroć i sprawiedliwość dają jej jednak za czyn niedoskonały nagrodę niedoskonałą. Już to nagradzam ją dobrami doczesnymi, już to użyczam jej czasu potrzebnego, aby się mogła poprawić. Niekiedy udzielam jej życia łaski ze względu na pośrednictwo sług moich, którzy Mi są mili i których wysłuchuję. Tak uczyniłem świętemu Pawłowi, który przez modlitwę świętego Szczepana wyrzekł się niewiary i prześladowania chrześcijan. Widzisz więc, że w jakimkolwiek by stanie dusza się znajdowała, nie powinna zaprzestawać dobrych uczynków ${ }^{21}$.

Dobro w aspekcie "niezniszczalnym”, wiecznym, wymaga konwersji, czyli przemieszczenia się $\mathrm{w}$ system obejmujący wszystkie aspekty życia w system religijny. Zgodne jest to ze współczesnym odczytaniem "zakładu” Blaise'a Pascala. Kontrowersje wokół „zakładu” dotyczą zwłaszcza ironicznego pomysłu na ukazanie dobra nieskończonego poprzez wyobrażenie sobie nieskończonego życia jako "nagrody" od Boga za wiarę w Niego. Tymczasem, wiemy chociażby z Ewangelii, że spełnianie uczynków ze względu na nagrodę nie jest godne pochwały.

Oprócz nielogicznego (ironicznego, szczególnie dla genialnego matematyka) pomysłu zestawienia skończoności z nieskończonością, Pascal promuje coś bardziej absurdalnego z punktu widzenia osoby stojącej na zewnątrz systemu religijnego. Opisuje zaiste "dziwną" (dla niewierzącego pojęcia o wierzącym) postawę jako godną naśladowania. Jest to postawa „uprzedzająca" łaskę wiary, postawa ni ewierzą cego praktykującego. Przyzwyczailiśmy się myśleć opozycją: wierzący praktykujący i niewierzący niepraktykujący. Ewentualnie częste są deklaracje postawy "pośredniej”: wierzący niepraktykujący. Z perspektywy "nawróconego” Pascala, ta ostatnia postawa jest niemożliwa, chyba że myślimy o oświeconych deistach zakładających jakąś Ideę Pierwszego Poruszyciela. Również pozycja pierwsza (wierzący praktykujący) nie jest postawą, lecz może być chwilowym stanem. Stanem "właściwym" kogoś, kto stara się o akces do systemu religii, jest praktykowanie bez względu na "próbę wiary”, której praktykujący poddawany jest bezustannie. Oprócz „,bazowego” poskromienia namiętności (podstawa sprawności: asceza), trzeba czynić coś jeszcze:

Chcesz iść ku wierze, a nie znasz drogi: chcesz się uleczyć z niedowiarstwa i żądasz leku: dowiaduj się u tych, którzy byli spętani jak ty, a którzy teraz zakładają się o wszystko, co mają; to ludzie znający drogę, którą chciałbyś iść; wyleczeni z choroby, z której ty chciałbyś się uleczyć. Naśladuj sposób, od którego oni zaczęli: to znaczy czyniąc wszystko tak, jak gdyby wierzyli, biorąc wodę święconą, słuchając mszy itd. W naturalnej drodze doprowadzi cię to do wiary i ogłupi cię²2.

21 Ibidem

22 B. Pascal, Myśli, w układzie J. Chevaliera, tłum. T. Żeleński (Boy), s. 200-201. 
Ogłupienie i wiara to jedno. Autor Myśli oczywiście wysoko ceni subtelną refleksję egzystencjalną i używanie rozumu, lecz przez swoje mocne słowa próbuje pokazać dylemat wiary. „Wiara jest relacją trójczłonową (X wierzy $\mathrm{Y}$, że p)"23, czyli wiara wymaga świadectwa, przede wszystkim świadectwa mocy $\mathrm{Y}$, a nie tylko świadectwa wiary $\mathrm{X} w$ tę moc. Stąd być może pochodzi źródłowa niemalże różnica między tak zwaną wiarą filozoficzną a wiarą religijną. „W akcie wiary religijnej podmiot nie tylko usiłuje wyjść poza siebie, lecz «spotyka się» ze swoim przedmiotem, będąc świadomym przepaści oddzielającej go od niego" 24 .

Kategoria dobra funkcjonuje inaczej w systemie religijnym i w pozostałych systemach społecznych. Zdaniem Luhmanna, gospodarkę, politykę i naukę, a od XVIII wieku także edukację zaliczyć należy do obszarów funkcjonalnych jako przekształcenia, zaś rodzinę i religię do tych, które je umożliwiają. Na to nakłada się powszechny proces prywatyzacji, który pozwala podnosić się społeczeństwu z różnego rodzaju, zwłaszcza ekonomicznych, kryzysów, lecz w polu religii skutkuje powszechnym i coraz bardziej uprywatnionym kryzysem wiary.

Poprzez prywatyzację religia dostaje się w odgraniczony od pracy i określony przez to obszar czasu wolnego. Tutaj rządzi nią coś w rodzaju „prawa Greshama”: małowartościowe rodzaje aktywności wypierają formy wysokowartościowe i - o ile doprowadzi to do ustalenia wyraźnych priorytetów (piłka nożna, oglądanie telewizji) - prawdopodobieństwo, że tak się stanie, wzmacnia się samo dzięki społecznym sprzężeniom zwrotnym ${ }^{25}$.

Luhmann podkreśla istnienie konfliktu między mikromotywami a makrozjawiskami. Mikromotywy nie dają się dostatecznie kontrolować w łonie makrozjawisk, czyli unormowanych kodów zachowań społecznych. Systemy napędzające przekształcenia zaczynają dominować nad umożliwiającymi je. Mikromotywy ustanawiają „zatargi” w ramach makrozjawisk, ale tak jak w tragedii greckiej można je jeszcze było wyrazić, dziś są niewidzialne.

$\mathrm{W}$ dobie prywatyzacji wzrasta (zwłaszcza w systemie religijnym) waga świadczenia. Jak pisze Luhmann: „zmniejsza się orientacja na funkcję, a zwiększa orientacja na świadczenia" 26 . Czy więc prywatyzacja, pociągająca za sobą sekularyzację, mogłaby stać się także źródłem odnowy religijnej? pyta.

Na poziomie samego systemu społecznego głębokie problemy najważniejszych systemów funkcjonalnych (jak nauka, gospodarka, polityka

\footnotetext{
${ }^{23}$ S. Wszołek, Racjonalność wiary, Kraków 2003, s. 119.

24 Ibidem, s. 120.

${ }^{25}$ N. Luhmann, Funkcja religii, tłum. D. Motak, Kraków 2007, s. 231.

${ }^{26}$ Ibidem, s. 255.
} 
czy edukacja) przybrały formę prywatności, która degraduje podstawowe problemy egzystencji społecznej do tego stopnia, że nie dają się one potem zsyntetyzować w przekonujące wzorce. Charakterystyczne dla religii odniesienia do świata $\mathrm{z}$ trudnością dają się aktualizować ad hoc (jak to systemy mają w zwyczaju robić ze swoimi odniesieniami). "Język wiary" nie jest na to przygotowany - stwierdzi Luhmann. Niebezpieczeństwo czai się zwłaszcza w tym, że „orientacja na świadczenie”, która jest skierowana do jakiegoś odbiorcy, wymaga często podporządkowania się prawom sukcesu i życzeniom oraz normom rzeczywistego lub „założonego" odbiorcy.

\section{Zasługa - najwyższe wcielenie dobra}

Zasługa to rezultat działania, który jest doceniony. Zasługę w ujęciu teologicznym tworzy zapośredniczenie dobra przez miłość. „Nikt nie ma większej miłości od tej, gdy ktoś życie swoje oddaje za przyjaciół swoich" $(\mathrm{J} 15,13)$. Dosłowne oddawanie życia za innych, którzy dodatkowo określają się jako nieprzyjaciele (czyli męczeństwo w ujęciu chrześcijańskim), to sprawność, którą rzadko (choć zdarzają się takie przypadki) można posiąść w "ostatnich" chwilach swojego życia. Raczej trzeba ją ćwiczyć całe życie. Lżejszą formą najwyższego gestu miłości są, według Edyty Stein, różne formy „zastępstwa”. Przy czym zaznaczyć trzeba, że ów najwyższy gest (oddania życia za nieprzyjaciół) nie miałby żadnego znaczenia, gdyby nie łączył się z modlitwą o ich zbawienie (co czyni z nich przyjaciół). Zastępca może:

wziąć na siebie zastępcze odcierpienie kary, za zgodą czy bez zgody winowajcy. Lecz może go także wybrać sam Sędzia i pozwolić mu cierpieć w zastępstwie winnego, nie czekając na jego deklarację ani nawet na jego zgodę. Bóg może pozwolić dzieciom odpokutować winy ojców, co nie sprzeciwia się zasadom ściśle prawnym. Zastępca jednakże powinien coś wiedzieć o sensie cierpienia zastępczego jako kary odcierpianej za kogoś, choć nie musi tego koniecznie rozumieć 27 .

Jeśli można wyrazić gotowość cierpienia za kogoś, żeby zmniejszyć karę za jego grzechy $\mathrm{w}$ oczach Boga, to można również komuś przyznać swoje zasługi i starać się o nagrodę dla niego - stwierdza Stein. Bóg może nagrodzić kogoś za coś, co zdziałał ktoś inny. W tym tkwi możliwość wstawiennictwa świętych, którzy spełniali uczynki bez względu na nagrodę. Ale „nawet najbiedniejszy człowiek, upokorzony ciężarem win, może i powinien

\footnotetext{
${ }^{27}$ E. Stein, Twierdza duchowa, tłum. I.J. Adamska OCD, Poznań 1998, s. 63.
} 
stanąć przed Panem i modlić się za drugich"28. Na tym polega roztropność „nieuczciwego rządcy” z przypowieści. Nie jest człowiekiem cnotliwym, lecz zrozumiawszy swój grzech, popełnia go „z korzyścią” dla bliźnich. Jego myślenie włącza „zasługę" Pana: zrobiłem źle, ale jeśli wykorzystam „dobra Pańskie" jeszcze raz, tyle że na rzecz innych, naprawię sytuację zarówno innych dłużników, jak i swoją własną.

Na to rządca rzekł sam do siebie: Co ja pocznę, skoro mój pan pozbawia mię zarządu? Kopać nie mogę, żebrać się wstydzę. Wiem, co uczynię, żeby mię ludzie przyjęli do swoich domów, gdy będę usunięty z zarządu (Łk 16, 3-4).

Rządca liczy na to, że inni mu się odpłacą, ale pośrednio zyskuje również „większe" dobro - pochwałę Pana.

Konkluzja, jak rozumieć „zasługę”, płynie z „wnętrza” systemu (religijnego). Tylko wewnątrz systemów działa funkcja je scalająca ${ }^{29}$. "Zasługa" mogłaby stanowić taką funkcję (samemu dla siebie zbawienia osiągnąć nie można).

Każdy system, dążąc do odróżnienia od innych („wyróżnicowania”) pisze Luhmann - zmienia się w swoją najwyższą formę. Tak zwana „religia wysoka" przetwarza wszystkie inne systemy jako "określone" na swoim polu ${ }^{30}$. Polityka, rodzina, sztuka są wchłaniane przez system nadrzędny.

Stosunek do społeczeństwa jako systemu nadrzędnego staje się sprawą funkcji; stosunek do innych systemów społecznych staje się sprawą świadczenia; stosunek do siebie samego staje się sprawą refleksji. Funkcja, świadczenie i refleksja nie mogą już więc być utożsamiane, a także nie mogą już więcej osiągnąć zwykłej operatywnej zgodności - w zasadzie w tym tkwi odpowiedź na pytanie o bariery funkcjonalnej specjalizacji systemów cząstkowych ${ }^{31}$.

Funkcję (system staje się nadrzędny), świadczenie (ustanawia swój stosunek do innych systemów) i refleksję (ustosunkowuje się do samego siebie) w systemie religijnym spina "zasługa”, czyli powszechna miłość, coś w rodzaju systemowej "parataksy” (woli przyłączania innych do systemu, np. w sposób dla nich nieodczuwalny, poprzez modlitwę).

Wejście w system religijny może być nagłe lub może być długotrwałym procesem „wyróżnicowywania się” systemu. Jedno i drugie wymaga nawrócenia. Jest ono często sygnalizowane przez zmianę imienia nawrócone-

\footnotetext{
${ }^{28}$ Ibidem, s. 65.

${ }^{29}$ Zob. N. Luhmann, Funkcja religii, op. cit., s. 37.

30 Zob. ibidem, s. 39

31 Ibidem, s. 57.
} 
go, jak u św. Piotra i św. Pawła. Św. Siostra Teresa Benedykta od Krzyża pisze Twierdze duchowa jeszcze jako Edyta Stein. Pisząc o zasłudze, antycypuje swój męczeński gest: skończoność jednostkowego życia oddaje za nieskończoność dobra. Te dwie „jakości” wydają się nie mieć ze sobą nic wspólnego (jak w "zakładzie” Pascala). Z punktu widzenia osoby spoza systemu śmierć męczeńska jest bezsensownym gestem, zwłaszcza jeśli można jej uniknąć.

Tylko z tej perspektywy można zapytać o "dobro wiecznotrwałe” z wnętrza systemu religijnego, gdy przyjęło się jedyną „właściwą", racjonalną, według Pascala, postawę - niewierzącego praktykującego. Dobro opisywane $\mathrm{w}$ kategoriach spoza systemu religijnego, nawet dobro moralne, to wartość skończona, wymierna i wymienna, a więc względna. Dobro „bezwzględne" realizuje się jednak jako zapośredniczenie, poprzez zasługę szczególny rodzaj „sprawności” zdobywania dobra „wiecznotrwałego” poprzez innych, dla innych, a dopiero potem również dla siebie. Nie można go bezpośrednio zdobyć dla siebie samego. Tylko zapośredniczenie dobra gwarantuje „wieczny sukces" w postaci zbawienia.

\section{Wnioski}

Rysują się tutaj dwa systemy ujmowania dobra - filozoficzny (dotyczący systemu etycznego) i religijny (zwłaszcza w odniesieniu do chrześcijaństwa, ale także do pozostałych religii monoteistycznych). Można sobie oczywiście wyobrazić ujęcia „mieszane” lub takie, które pozwalają się spotkać tym systemom w konkretnym punkcie - pojęciu lub przedstawieniu (św. Tomasz, Pascal, Lyotard), lecz w ogólnej perspektywie należy te ujęcia rozpatrywać rozłącznie, ponieważ $\mathrm{w}$ pierwszym ujęciu na plan pierwszy wydobywane jest uzasadnienie racjonalne (osiąganie konkretnego dobra w czasie blokuje możliwość reinterpretacji sytuacji etycznej z innej perspektywy, np. ofiary), a w drugim - personalne (sytuacja etyczna może mieć dalekosiężne i dalece zapośredniczone konsekwencje w relacjach międzyludzkich, ponieważ uwzględnia się tu czynnik nadprzyrodzony, np. łaskę).

\section{Two Systems of Good? - a Phenomenon of Proficiency}

Summary

In this article two systems of understanding of good are presented: first, the philosophical one (connected with ethical system), and second - religious one (espe- 
cially in case of Christianity, but also other monotheistic religions). It is possible, of course, to imagine a "mixed" system or one where those two could meet each other in specific point, or concept, or representation. In general, those systems have to be considered separately. Rational explanation is crucial for a philosophical system (achieving a specific good makes a reinterpretation of ethical situation from different point of view, for example as a sacrifice, impossible), while religious system needs a personal explanation (ethical situation could have a far-reaching consequences for interpersonal relations, because a supernatural factor, for example a grace, is included here). 